\title{
Study on the Financing Strategies of High-tech Small and Medium
}

\section{Enterprises}

\author{
Junpeng Wang ${ }^{1}$, LiaiLun Chen ${ }^{1}$
}

${ }^{1}$ Wuhan Donghu University, Wuhan, Hubei Province, 430212

\section{KEYWORDS: Financing Strategies; High-tech Small and Medium Enterprises; Economy Policy}

\begin{abstract}
China today, the growth of high-tech small and medium enterprises are increasingly becoming the implementation of national technology innovation strategy, as well as to promote the sustained, stable and indispensable force in the fast-growing, high-tech small and medium enterprises but restricts healthy growth and development of financing disorder has not been fundamentally changed. In addition to multi-objective conditions of the external environment of the fish to be further improved, focusing on high-tech start-growing small and medium enterprises themselves, how to take practical policy measures to get rid of financial difficulties, remains sufficiently high growth, is an urgent need for further academic explore and solve problems. In recent years, research on SMEs or high-tech enterprise financing mechanisms, financing and environmental aspects of the financing system more, but less specialized high-tech, Growth Analysis of policies for SME financing. Thus, this thesis stand questions of practical value and theoretical significance.
\end{abstract}

\section{Introduction}

Small groups of small and medium high-tech enterprises is the most striking, the most promising, with its strong technical innovation and professional impulses, not only for the incubation of new industries, activate regional economy provide an important basis for the development of high-tech to become technology industry an important subject and the establishment of national innovation system, but also to promote industrial upgrading, improve the economic competitiveness of the basic forces. Therefore, my Government to the development of small and medium high-tech enterprises as the national science and technology policy, or an important part of the high-tech industry policy, and actively create favorable conditions and basis of social, economic, financial and other technical aspects to accelerate the rapid growth of small and medium enterprises and high-tech healthy growth.

Severe funding shortages growth and development of small and medium high-tech enterprises encountered inevitably exposed. Money is the blood, is the first impetus of economic activities and sustainable driving force. With the growing market competition, to achieve rapid growth of high-tech small and medium enterprises must maintain funds benign circulation and flow. According to statistics, there are almost a fifth stage of the small high-tech growth companies due to financial problems themselves in financial straits. Thus, under the new historical period of the 21st century, high-tech small and medium enterprise financing environment has become more complex, capital intermediation are thus faced with more opportunities and challenges. Small and medium enterprises financing high-tech growth, particularly in-depth study of the various stages of development based on their own how to overcome the growing financing beep seek to achieve innovative financing strategies facility, has practical significance. 


\section{Medium and Small High-Tech Business Growth Connotation}

The concept is an extension of the high-tech concept comes from the high-tech, high-tech word (HighTechn01ogy, the abbreviation of a High tech) originated from the United States. Office of National Science and Technology Achievements defined as high-tech: the establishment of comprehensive scientific research, based on modern science and technology in the forefront of the development of productive forces, promote social civilization and national strength plays the leading role of new technology base. Its basic features are obvious strategic, risk, value-added, J wins penetration, knowledge, talent and technology-intensive investment group.

Growing phase of small high-tech companies in business research and development of high-tech products than the major, high input costs and a large amount of research and development of scientific and technological personnel, scientific and technological content, low material costs account for the proportion of product prices, added value, the proportion of intangible assets in the whole lot. These knowledge-based patents, proprietary technology, trademarks, goodwill and other intangible assets enable enterprises to obtain excess profits. And because the height of high-tech products and the timeliness of product replacement has fast and so fierce market competition, corporate risk. Therefore, this type of enterprises in their development process, has been running at a high risk zone, the lower the survival rate. According to researchers of the US Small Business lifetime, about 68 per cent in the first five years closed down 19 percent can survive six to 10 years, only $13 \%$ over 10 years. Since the reform and opening up of the emergence of a number of small and medium high-tech enterprises, is now only $20 \%$ to $30 \%$ is still evolving.

\section{Demand for High-Tech Growth of Small Business Financing}

First, the high-tech small and medium enterprises demand a huge amount of funds. Studies have shown that a new technology from research and development to commercialization of each stage funding requirements ratio) research: development: commercial capital requirements = 1: 10: 100; According to the China Statistical Yearbook 520036 show, our 2002 investment in research and development (R \& D) funding for 116.1 .1 million, the ratio between the above may be initially estimated, the financial needs of the commercialization of scientific and technological achievements more than 1.1 trillion yuan more than a year.

Secondly, small and medium high-tech enterprise demand for capital has its life-cycle consistent with obvious stage characteristics. According to the experts to statistics, the total amount of funds every stage of the United States venture approximately: 50 seeds usually for a one million dollars; the creation of a general US \$ 502.5 million; US \$ 200 for the general expansion of a 30 million; general maturity above US \$ 30 million.

\section{Small High-Tech Companies Financing Obstacles and Capacity Analysis}

Adverse selection and moral hazard caused by asymmetric information is a high-tech growth of small and medium enterprises financing difficulties underlying causes. Investment and financing process, as an investor or creditor and as a donor of funds between small and medium high-tech corporate finance presence of asymmetric information, in relative terms, the total capital has some of the demand side is not the supply side of the external funding known, information about the internal operations, including all aspects of finance, so as small and medium high-tech corporate finance significant information in a dominant position.

The lack of credit: stage high-tech small and medium enterprises credit awareness, awareness of information disclosure, standardized financial management level witch to be further strengthened. 
Unable to establish a business in the credit market, a good reputation, so that the capital provider in the financial markets for small and medium high-tech enterprises of bad behavior expectations subjective constitute obstacles to external credit financing.

Asset-light features: high-tech small and medium enterprises to high-tech as the core of intangible assets such as patents, proprietary technology, an impact on the survival and development of the important factors of production, higher intangible assets in total assets in proportion. Lack of general mortgage financing can be secured or tangible assets, such as machinery and equipment, buildings, land or physical inventory, which does not have the advantages of traditional channels of financing conditions.

System supply conditions inadequate: the four state-owned commercial banks as the main body, a high concentration and monopoly of the financial system itself, the lack of suitable offers small and medium enterprises, including technology or growth of small and medium enterprises and services a population boom financial intermediaries, institutional supply shortage caused by objective obstacles main external financing environmental conditions.

Lack of financial market conditions, direct financing system is not complete bank financing: banks lending the main criteria are the credibility and ability to repay. Small high-tech integrated enterprise credibility has not been fully established, the anti-risk ability is not strong, it is difficult to obtain bank loans. If the banks to invest in high-risk enterprise, the pursuit of stability not only to the principles and interests of depositors contrary, short-term liquidity and capital structure of the bank liabilities of itself does not support long-term investment spending will lead to payments crisis. Bond financing: at the start of the growth and development of small and medium sized high-tech enterprises, there are a number of uncertainties and other technologies and markets, bond financing way difficult to get investors recognized. Venture Capital Financing: The domestic venture capital institutions are focusing on short-term return on investment, the real spirit of the modern stage venture investment philosophy spirit, willing to take risks to support small and medium high-tech enterprises to support growth and development is very small. Stock issuance of financing: the current market conditions motherboards or small board market, the need for consecutive profitable years and reached 50 million shares of the scale of the high-tech, high-growth, good prospects for the development of start-ups in terms of equity financing threshold is too high. And Chinese multi-level capital market system, including GEM has not yet been fully established.

\section{Financing Strategy Selection of Small High-tech Growth Companies}

Policy financing is ideal for those with a business or industrial advantages, high technology, with independent intellectual property rights, or in line with national industrial policy, small and medium high-tech projects typically require companies to run well, and reach a certain size, a certain business foundation management Wait. Government set up various policy financing instruments, in accordance with the needs of the country aimed at economic restructuring and technological innovation, to encourage small and medium technology enterprises rely on government paid part of the funds raised on the basis of the unpaid support and guidance, accelerate scientific and technological achievements industrialization process of enterprises to promote the healthy growth and create new jobs, and achieved good economic and social benefits.

And in the fast-growing small and medium sized high-tech enterprises consistent government focus on supporting and guiding the development of audiences, so companies themselves should actively pay attention to the effectiveness of policy financing, while financing policy as a useful means of financing and financing strategies into the daily management of them. However, most domestic companies often ignore policy financing instruments, operating behind closed doors, do 
not understand or did not want to deal with government departments, not to mention the use of the policy. In fact, how to strategically grasp and apply the policy of financing for enterprises to reduce financing costs, effective grafting to integrate government resources platform, to solve the bottleneck of the development funds can play a considerable role.

After gathering in groups small and medium high-tech enterprises will be able to exceed and to form single distinct individual financing advantages. Business area within the set of high-tech industry by industry, by region, according to the financial needs of commonality financing can form strategic alliances, implementation of collection financing strategy, not only a unique industrial cluster environment increases the trustworthiness of the enterprise, reduce financial institutions financing risks, so that the financing of scale effect and the multiplier effect, a virtuous cycle of development to promote the growth of enterprises, financial institutions, regional economic inter-; and through the joint enterprise to the financial markets, you can share strategies and information resources financing, shared responsibility financing risks, to develop a wide range of financing channels. In addition to this strategic alliance, but also large companies take the road of joint listing and financing; also jointly funded the establishment of mutual funds or guarantee funds, the establishment of credit guarantee institutions for small and medium high-tech enterprises and services, to provide credit for the co-financing of enterprises guarantee.

Small high-tech growth companies should actively implement the credit financing strategies, pay attention to establish their own image of financial credit, and gradually establish a reputation financing, risk management and financing to be included among the financing of strategic management, financial risk control, corporate financing behavior of the market has sustainability. Whether it is integrated into the equity capital or debt capital, financing should be entering into a good relationship with the supply of capital, investors should take the initiative and contact them about the market prospects of the business operations and products, understand the general situation of financing projects in order to promote trust, establish a good credit image, thereby reducing transaction costs.

Between enterprises and financial institutions exist under asymmetric information, and actively explore the establishment and improvement of credit guarantee system based indirect financing system, to play and to strengthen the function and role of credit guarantee system, but for the presence of the financing process information asymmetry problem, take innovative financing strategies such as seeking financing from the enterprise business suppliers, vendors and other related parties: the strategic initiative to give the necessary control over a management equity investors; financial lease or operating leases, etc., to solve practical problems of financing enterprises and promote the sustained high growth and development will play a positive role.

\section{Conclusion}

Maximize enterprise value is a business goal, and developed and implemented financing decision will directly affect the company's operating results. As one of the important business decision making, only fully understand the internal and external financing environment information, follow scientific procedures, local conditions to planning and financing strategies in order to finance neither blind, but also to meet normal business in ensuring the premise of minimizing financing costs operation and development of the necessary funds.

\section{Reference:}

[1] Heinkel, Robert. A Theory of Capital Structure Relevance Under Imperfect Information[J]. 
Journal of Finance, 1982, (3).

[2] Myers, S. C. and Majluf, N. S., 1984, Corporate Financing and Investment Decisions when Firms have Information that Investors do not have [J]. Journal of Financial Economics, Vol.13.

[3] Don Egginton. Divisional performance measurement: residual income and the assets base [J]. Management Accounting Research, 1995, (6), pp.201-222.

[4] Frank, M. Z.and Goyal, V. K .Capital Structure Decisions [J]. Working paper, University of British Columbia, 2003. 